\title{
Genetic Diversity Analysis of Elops machnata (Forskal) Populations in South East and West Coasts of India Using RAPD Markers
}

\author{
Vellaichamy RAMANADEVI, Muthusamy THANGARAJ* \\ Annamalai University, Centre of Advanced Study in Marine Biology, 608502 Parangipettai, Tamil Nadu, \\ India; coralholder@yahoo.com (*orresponding author)
}

\begin{abstract}
The Random Amplified Polymorphic DNA (RAPD) technique was used to study the genetic diversity of four Elops machnata populations in South India. Elops machnata is considered as a least concern species (LC), categorized by the International Union for Conservation and Nature (IUCN). The population trends are currently stable in Indian Ocean, Eastern Africa, but are unknown throughout the rest of its expansive range, especially in Indian estuaries. Among the ten RAPD primers tested, eight primers got amplified and gave scorable bands. In total, 119 scorable bands were observed in all populations. The overall observed and effective number of alleles was found to be $2.000 \pm 0.000$ and $1.5307 \pm 0.2503$ respectively for the entire population. The overall polymorphic loci were $61.00 \%$ and the overall gene flow among the four populations was predicted to 0.1032 . The genetic distance and geographic distance between the four populations showed a positive correlation. The highest genetic similarity (0.6824) was found between Parangipettai and Muthupettai population, which reflected the geographical relationship between them. Tow main clusters were obtained based on UPGMA dendrogram. This study proves that RAPD analysis has the ability to discriminate E. machnata populations in South Indian coastal waters.

Keywords: gene flow, genetic distance, ladyfish, polymorphism
\end{abstract}

\section{Introduction}

Elops machnata, also called ladyfish, is found in marine or brackish water with wide distribution especially in tropical regions in Indo-West Pacific. E. machnata's early life stages use estuary and lagoonal habitats, which are prone to anthropogenic alterations but this species exhibits a broad range of habitat plasticity (Adams et al., 2012). A number of questions remain unanswered regarding to their taxonomic uncertainty, population status, fisheries interactions and potential threats in the eastern part of its range. Future monitoring is needed, mainly in the Coral Triangle, where significant declines in other Elopiformes have been inferred (Adams et al., 2012). Results of the study done by Mwandya et al. (2009) indicate that mangrove habitat loss and changes in environmental conditions appeared. These changes were caused by salt farm developments which decreased fish density, biomass and number of species, as well as alter overall fish assemblage composition in the salt farm area. The unknown extent of commercial fisheries and the magnitude of harvest mean a potential threat to this species.

Genetic diversity and the biodiversity level deals with the genetic characteristics of the organisms that plays a major role in the survival and adaptability of the species (Frankham, 2005). The ability of organisms to challenge the adaptability to their changing environment leads to its survival and causes rise in genetic variation (Pullin, 2002). The combined effects of deterministic factors such as habitat loss, pollution, introduction of exotic species, over exploitation and stochastic factors such as catastrophic effects, environmental changes, demographic effects, genetic factors are being considered to be major threats in biological extinction (Shaffer, 1981). In addition, Frankel and Soule (1981) revealed the deleterious effects of inbreeding and affirmed that genetic factors had an important role in causing species extinction. Moreover the accumulation of mutations in the genome has the capacity to determine the fitness of the organisms (Lande, 1995; Lynch et al., 1995).

The Random Amplified Polymorphic DNA (RAPD) is a PCR based DNA fingerprinting techniques with random generation of amplified DNA fragments using short oligo nucleotide primers (Welsh and McClelland, 1990). The RAPD fragments are following Mendelian fashion, dominant inheritance, showing high polymorphic content and specifically no need of genetic information (Bardakci and Skibinski, 1994). Even though many debates arise on reproducibility of RAPD, it could be overcome by following constant concentration and stringent PCR conditions (Micheli et al., 1994; Dinesh et al., 1995). RAPD fingerprinting technique had been used in several studies including generation of species-specific markers in catfish species (Liu et al., 1998), genetic differentiation studies among strains and populations of catfishes (Liu et al., 1999a), population differentiation in mud crabs (Klinbunga et al., 2000) and phylogenetic relationship in Barbus species (Callejas and Ochando, 2002).

Population structure assessment studies were carried out in several species like Polynemus plebeius (Indian salmon) 
400

(Thirumaraiselvi et al., 2013), Lates calcarifer (Indian seabass), Pecten maximus (great scallop) (Heipel et al., 1998), Lepeophtherius salmonis (copepode) (Todd et al., 1997) and Homarus americanus (American lobster) (Harding et al., 1997) by RAPD markers.

Population diversity studies give better knowledge for taking efforts in the management of Elops species in the wild populations. Their effective management leads to healthy broodstocks development in order to sustain commercially demanded areas. Until now, no studies have been done to report the genetic structure of E. machnata populations in India using RAPD markers. The goal of this work was to examine the extent of genotypic variability of intra- and inter- populations of this least concern species, $E$. machnata in Tamilnadu and Kerala coasts.

\section{Materials and methods}

\section{Sampling locations}

The four populations including Marakanam $\left(12^{\circ} 12^{\prime} 0^{\prime \prime}\right.$

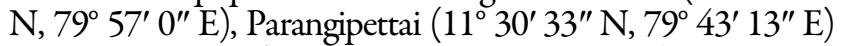
and Muthupettai $\left(10^{\circ} 23^{\prime} 0^{\prime \prime} \mathrm{N}, 79^{\circ} 30^{\prime} 19^{\prime \prime} \mathrm{E}\right)$ estuaries of Coromandel Coast and Cochin ( $9^{\circ} 58^{\prime} 4.8^{\prime \prime}$ N, 76 14' 38.4" E) estuary of Malabar Coast were selected for this study (Fig. $1)$.

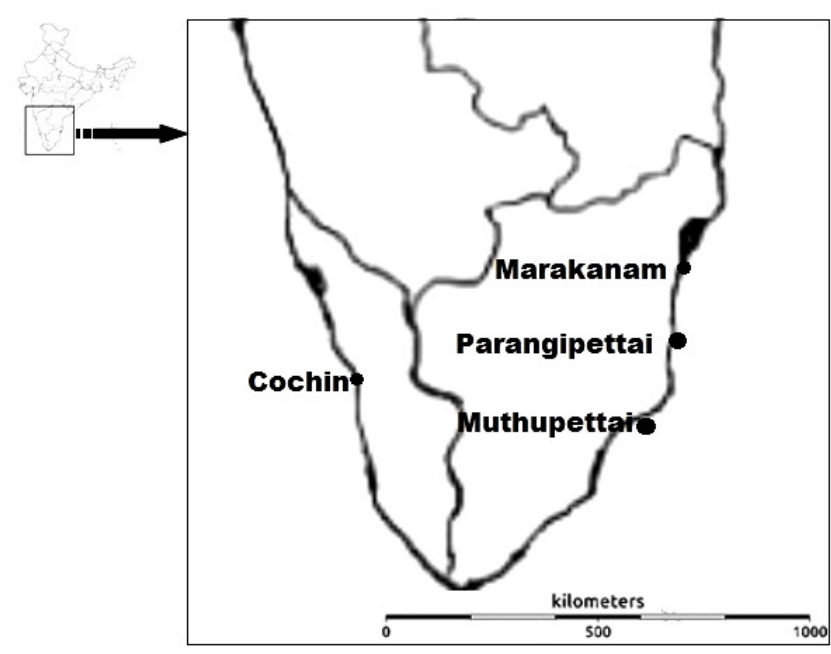

Fig. 1. Map showing the study regions

\section{Sample collection}

E. machnata finclips were collected from Marakanam, Parangipettai, Muthupettai and Cochin along both east and west coasts of South India. Totally 100 samples were selected and the tissue samples (caudal fin) were stored in 95\% ethanol for further analysis.

\section{DNA isolation}

DNA was isolated from the stored samples by the standardized salting-out procedure (Sambrook et al., 1989). Quantity of the extracted DNA was checked in UV spectrophotometer by taking the optical density (OD) at 260 $\mathrm{nm}$ and $280 \mathrm{~nm}$.

\section{Polymerase chain reaction}

Ten oligonucleotide primers were used to analyze genetic diversity and to identify species-specific markers in four populations of E. machnata. The amplification reaction was carried out in a $25 \mu \mathrm{L}$ reaction volume containing 10 mMTris- $\mathrm{HCl}, \mathrm{pH} 8.3,1.5 \mathrm{mM} \mathrm{MgCl}, 100 \mu \mathrm{M}$ each of dATP, dCTP, dGTP and TTP, $0.2 \mu \mathrm{M}$ of each primer, $1 \mathrm{U}$ of Taq DNA polymerase and $50 \mathrm{ng}$ of genomic DNA. RAPD-PCR was performed in a Thermalcycler for 40 cycles consisting of denaturation at $94^{\circ} \mathrm{C}$ for $30 \mathrm{sec}$, annealing at 45 ${ }^{\circ} \mathrm{C}$ for $30 \mathrm{sec}$ and extension at $72{ }^{\circ} \mathrm{C}$ for $60 \mathrm{sec}$. The final extension was carried out at the same temperature for $5 \mathrm{~min}$.

The resulting PCR products were electrophoretically analyzed through $1.5 \%$ agarose gels stained with ethidium bromide and visualized using a UV transilluminator. Molecular weights of the bands were calculated with reference to the molecular weight markers with the gel documentation system. Only high intensity scorable bands were taken for genetic variation analysis. The sizes of the DNA fragments were assigned according to the molecular weight marker ( $100 \mathrm{bp}$ ladder).

\section{Data analysis}

Genetic similarity/distance between the four E. machnata populations was estimated using PopGen Software (Version 1.31, Yeh et al., 1999). Nei and Li's (1979) genetic similarity (GS) among the four populations was computed and converted by PopGen into genetic distance (GD) according to Hillis and Mortiz's (1990) formula: GD = 1-GS. The GS reflects the proportion of the bands shared between individuals and values ranges from (1) when present to (0) when absent.

\section{Dendrogram}

Phylogenetic relationship was estimated based on genetic distance values generated from RAPD data among four populations of E. machnata. The dendrogram was plotted based on Nei (1978) method using PHYLIP Version 3.2. A neighbour joining tree was also generated using PopGen (Yeh et al., 1999).

\section{Results}

The genomic DNA was isolated from E. machnata from four populations that have shown shown clear bands in $0.8 \%$ agarose gel electrophoresis. The amount of DNA present in all the isolated samples was ranging from $1 \mu \mathrm{g}$ to $2 \mu \mathrm{g}$.

\section{Estimation of genetic variation by RAPD}

Among the ten RAPD primers, eight primers got amplified and gave scorable bands. Fig. 2 shows the RAPD banding pattern of eight arbitrary primers obtained from the four populations of E. machnata. Each primer showed population specific RAPD fingerprint profile. Bands were presented ranging from higher molecular weight to lower molecular weight. Totally 119 scorable bands were observed in all populations. They were 27 bands in Cochin, 31 bands in Marakanam, 32 bands in Muthupettai and 29 bands in Parangipettai population. The primer name and size range details are given in Tab. 1.

\section{Observed number of alleles ( $\mathrm{Na}$ )}

This index measures the sum of all detected alleles in all loci, divided by the total number of loci. Due to the dominant nature of the RAPD marker, the number of allele per loci was 
Tab.1. Number and size of the fragments produced by eight RAPD primers and molecular weight of the bands in four populations of E. machnata

\begin{tabular}{|c|c|c|c|c|c|}
\hline \multirow{2}{*}{ RAPD primers } & \multicolumn{4}{|c|}{ No. of fragments (Size range in bp) } & \multirow{2}{*}{$\begin{array}{c}\text { Total No. } \\
\text { of fragments }\end{array}$} \\
\hline & Cochin & Marakanam & Muthupettai & Parangipettai & \\
\hline An3 & $3(1100-235)$ & $4(1100-235)$ & $4(1100-315)$ & $4(1050-290)$ & 15 \\
\hline An4 & $5(1000-280)$ & $5(1100-400)$ & $4(950-325)$ & $4(960-115)$ & 18 \\
\hline An5 & $4(580-150)$ & $5(1000-150)$ & $3(625-159)$ & $3(625-155)$ & 15 \\
\hline An6 & $3(960-270)$ & $4(1005-450)$ & $3(960-380)$ & $3(960-700)$ & 13 \\
\hline An7 & $3(1200-635)$ & $4(1200-502)$ & $4(880-290)$ & $3(660-405)$ & 14 \\
\hline Ans & $4(1400-360)$ & $3(1400-620)$ & $4(1400-700)$ & $3(1200-720)$ & 14 \\
\hline An9 & $2(1000-395)$ & $3(1500-620)$ & $5(1050-400)$ & $5(1000-470)$ & 15 \\
\hline An10 & $3(970-325)$ & $3(1400-330)$ & $5(1700-290)$ & $4(1075-270)$ & 15 \\
\hline Total & 27 & 31 & 32 & 29 & 119 \\
\hline
\end{tabular}

A
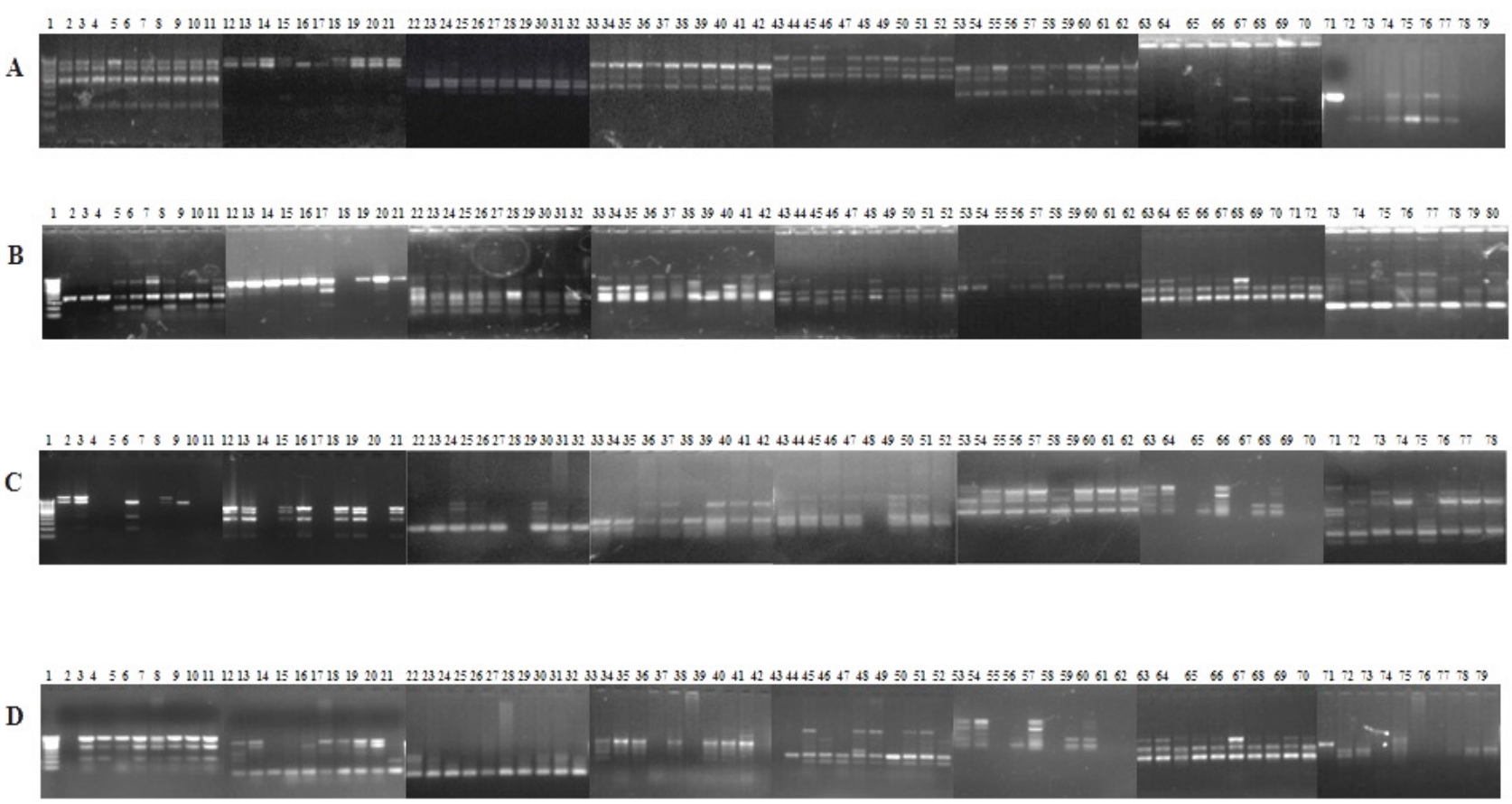

Fig. 2. RAPD banding pattern of E. machnata by eight primers (A-Cochin; B-Marakanam; C-Muthupettai; D-Parangipettai)

considered to be two alleles (maximum) for each locus. The observed number of alleles in all populations is depicted in Tab. 2. Observable values were noticed in Marakanam and Muthupettai populations that showed the $\mathrm{Na}$ values of $1.1889 \pm 0.3936$ and $1.1556 \pm 0.3645$. In Cochin population, the observed number of alleles per locus is comparatively less $(1.111 \pm 0.3160)$. Totally 25 individuals were taken from each population for this analysis. It simply suggests that some of the alleles were absent in Cochin population. The reason might be mutations that have taken place in some priming regions. The overall number of alleles was found to be $2.000 \pm 0.000$ for all the population.

\section{Effective number of alleles $(\mathrm{Ne})$}

This value deals with the number of alleles that would have been expected in a locus in each population. In Marakanam population, the effective number of allele was $1.1318 \pm 0.3126$. In the present study, the effective number of alleles in all the populations was found as $1.5307 \pm 0.2503$. This higher value indicates that more numbers of alleles can be effectively reproduced in the future by RAPD primers. It will be helpful to monitor the genetic status of these $E$. machnata populations in the successive periods.

\section{Nei's gene diversity and Shannon information index}

The allelic diversity was measured through Nei's genetic diversity for all the populations. All the populations showed more or less similar range of genetic diversity. Among the four populations Marakanam showed highest genetic diversity of $0.0718 \pm 0.1641$. The lowest genetic diversity of $0.0322 \pm$ 0.1061 was observed in Cochin population. In Muthupettai and Parangipettai population the genetic diversity was 0.0666 \pm 0.1588 and $0.0538 \pm 0.1385$ respectively based on RAPD data.

Shannon information index measures the diversity of allelic variation between the individuals of a particular and overall population. In the present investigation, the Shannon's index is higher in Marakanam population. Very few index of $0.0496 \pm 0.1563$ was observed in Cochin population. Genetic diversity and Shannon's information index showed that the four population of E. machnata were large enough to show results, shown in Tab. 2.

\section{Polymorphic loci in four populations}

In all four populations, the observed percentages of polymorphic loci were in the range of 11.11 to 18.89 (Tab. 2). 
402

Among the four studied populations, Marakanam population showed $18.89 \%$ polymorphic loci in all the eight primers. The overall polymorphic loci were $61.00 \%$ by the eight RAPD primers used in this study. The overall gene flow among the four populations by the eight RAPD primers was predicted to 0.1032 by Nei's analysis of gene diversity in subdivided population.

Tab. 2. Overall observed number of alleles $(\mathrm{Na})$, Effective number of alleles $(\mathrm{Ne})$, Gene diversity (H), Shannon's Information index (I), Number of polymorphic loci $(\mathrm{Np})$ and Percentage of polymorphic loci $(\mathrm{Pp})$ in four populations of $E$. machnata

\begin{tabular}{lccccc}
\hline Populations & $\mathrm{Na}$ & $\mathrm{Ne}$ & $\mathrm{H}$ & $\mathrm{I}$ & $\mathrm{Pp}(\%)$ \\
\hline \multirow{3}{*}{ Cochin } & 1.111 & 1.0531 & 0.0322 & 0.0496 & \\
& \pm & \pm & \pm & \pm & 11.11 \\
& 0.3160 & 0.1831 & 0.1061 & 0.1563 & \\
Marakanam & 1.1889 & 1.1318 & 0.0718 & 0.1046 & \\
& \pm & \pm & \pm & \pm & 18.89 \\
& 0.3936 & 0.3126 & 0.1641 & 0.2327 & \\
Muthupettai & 1.1556 & 1.1206 & 0.0666 & 0.0960 & \\
& \pm & \pm & \pm & \pm & 15.56 \\
& 0.3645 & 0.2945 & 0.1588 & 0.2272 & \\
Parangipettai & 1.1444 & 1.0923 & 0.0538 & 0.0797 & \\
& \pm & \pm & \pm & \pm & 14.44 \\
& 0.3535 & 0.2463 & 0.1385 & 0.2019 & \\
Overall & 2.0000 & 1.5307 & 0.3279 & 0.4997 & \\
& \pm & \pm & \pm & \pm & 61.00 \\
& 0.0000 & 0.2503 & 0.1188 & 0.1490 & \\
\hline
\end{tabular}

\section{Nei's genetic identity and genetic distance}

Tab. 3 shows the genetic identity and genetic similarity between the four populations calculated by Nei's algorithm from the RAPD fingerprint profile. By this analysis, the study showed that the genetic similarity between the populations were high when they were compared to genetic variability between the populations. Whereas the highest genetic similarity (0.6824) was found between Parangipettai and Muthupettai populations, which reflected the geographical close relationship, the lowest genetic identity was identified between Parangipettai and Cochin populations.

Genenetic and geographic distances between the four populations (Fig. 3) showed a positive correlation.

Tab. 3. Nei's Genetic identity (above diagonal) and genetic distance (below diagonal) of four populations of E. machnata

\begin{tabular}{lcccc}
\hline Populations & Cochin & Marakanam & Muthupettai & Parangipettai \\
\hline Cochin & ${ }^{* * * * *}$ & 0.6237 & 0.5871 & 0.5506 \\
Marakanam & 0.4720 & ${ }^{* * * * * *}$ & 0.6231 & 0.6314 \\
Muthupettai & 0.5326 & 0.4730 & ${ }^{* * * * * *}$ & 0.6824 \\
Parangipettai & 0.5967 & 0.4598 & 0.3821 & ${ }^{* * * * * *}$ \\
\hline
\end{tabular}

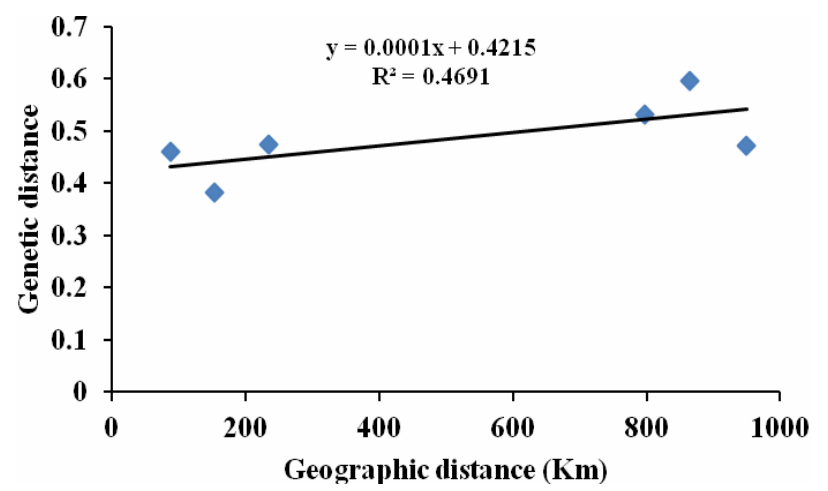

Fig. 3. Genetic distance in relation to geographic distance among the four populations

\section{Dendrogram}

Dendrogram based on the relationships between the four E. machnata populations was constructed using Nei's genetic distance by UPGMA algorithmand shown in Fig. 4. The branch length indicates the genetic distance between the populations. The Marakanam and Cochin population formed a close cluster. It indicates that the genetic similarity was high between these two populations. Parangipettai population showed a sister relationship with Muthupettai population. This dendrogram reflect the relationship among the four populations as morphometric results show.

RAPD is a quick and cost-effective molecular technique by generating anonymous loci that are randomly scattered in the genome (Clark and Lanigan, 1993). Ali et al. (2004) reviewed the efficiency of RAPD on population differentiation and establishment of genetic relationship among fish populations.

In the present study, the genetic variability was investigated in the four populations of $E$. machnata by eight arbitrary RAPD markers as per earlier reports (Williams et al., 1990; Welsh and McClelland, 1990). In this study, the RAPD markers were identified for each population using eight arbitrary primers. In total 119 bands were obtained from four populations and found the level of inter- and intrapopulation genetic variation. These numbers of loci seemed appropriate which were used previously in the assessment of genetic variation study (Lynch and Milligan, 1994). In all populations, the total polymorphic percentage was observed as 61.00 and the average polymorphic loci were $15.25 \%$ in each population. Similarly, this low polymorphic percentage of about $20.55 \%$ was found in a single population of critically endangered yellow catfish, Horabagrus nigricollaris collected from Challakudy river in India (Muneer et al., 2011). Generally, RAPD markers showed higher polymorphic percentage like $60.48 \%$ polymorphic percentage in the Malaysian river catfish, Mystus nemurus (Chong et al., 2000) and $61.05 \%$ polymorphic percentage in the channel catfish, Ictalurus punctatus and I. furcatus (Liu et al., 1998). As compared to previous studies, $68 \%$ of polymorphic loci were reported in three populations of catfish, Clarias batrachus in three water bodies of Bhopal in India (Mehrotra et al., 2010). Rahman et al. (2009) studied the genetic variations of wild and hatchery populations of Catla catla revealed by RAPD markers and found a $54.55 \%$ overall polymorphism. Shifat $e t$ al. (2003) have also reported RAPD Jaccards dissimilarity coefficient in 34 individuals of Tenualosa ilisha and observed 20.41\% polymorphism. This low level of polymorphism obtained from the present study strongly correlates with previous studies on genetic variability of species. It states that genetic variation within species should positively correlate with the population size and as a consequence, genetic variation of endangered species is expected to be lower than in non-endangered species (Frankham, 1996). This result likely states in agreement with the above mentioned idea that $E$. machnata could be considered as an endangered species due to its low level of genetic variation.

The molecular weight of 119 RAPD-PCR fragments in four populations of $E$. machnata ranged from $115-1,700 \mathrm{bp}$. Some authors reported that the number and size of the fragments generated strictly depend on the nucleotide sequence of the primers that act on the template DNA, 


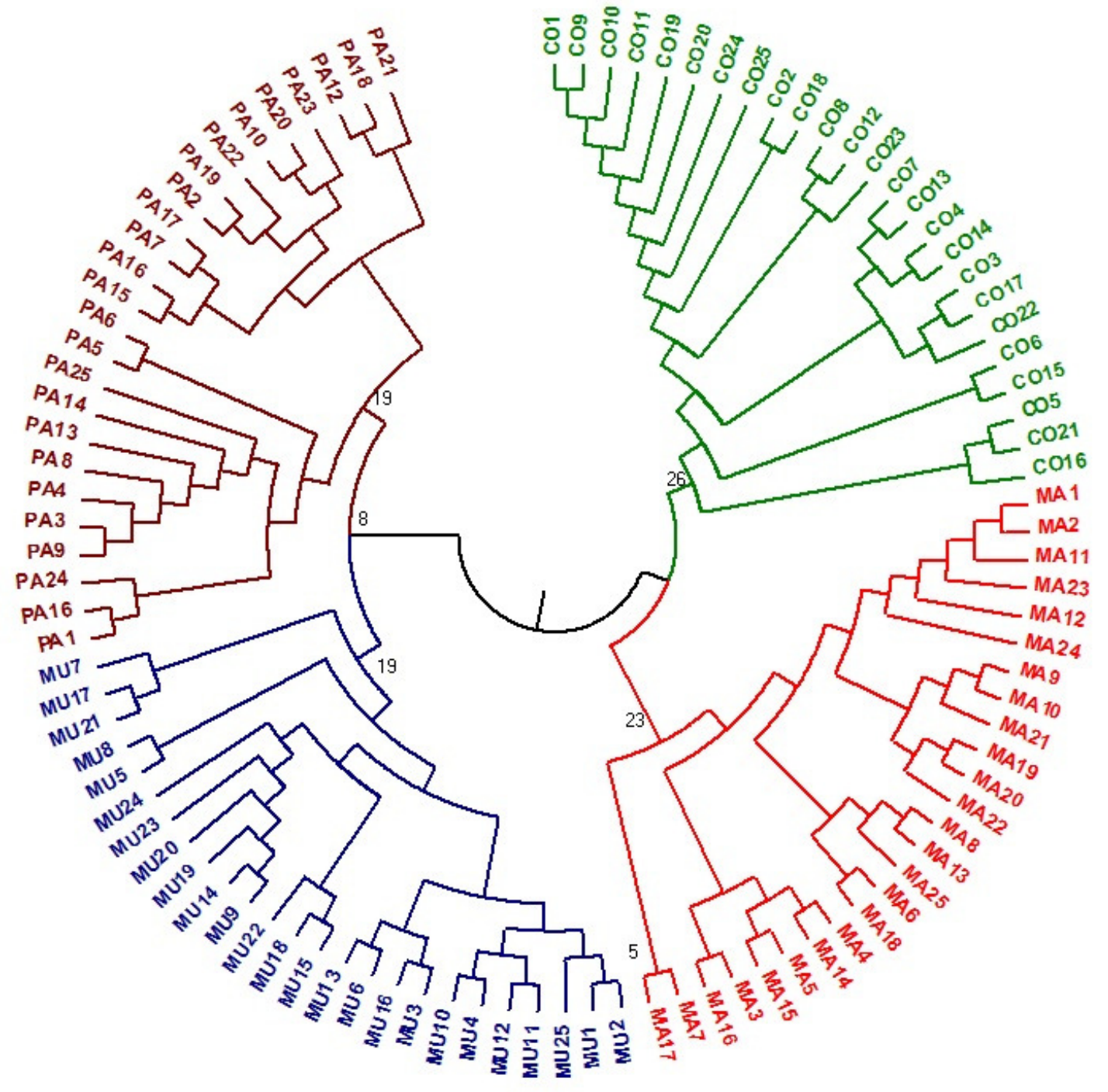

Fig. 4. Dendrogram Based Nei's Genetic distance (CO: Cochin; MA: Marakanam; MU: Muthupettai; PA: Parangipettai)

generating genome-specific fingerprints from the amplified random DNA fragments (Welsh et al,, 1991). However, previous reports proved that there was no correlation between the length of the primer and number of amplified products, but good correlation arises between $\mathrm{G}+\mathrm{C}$ content of the primer and number of amplified products (Caetano-Anolles et al., 1991; Dong and Zhou, 1998). The G+C content of the primers used in the present study were found to be almost similar, hence the number of RAPD amplified fragments also was similar except some primers (Tab. 1). Previously, Liu et al., (1999a) found that 200-1,500 bp RAPD fragments showed reproducibility in catfish population, $I$. punctatus and $I$. furcatus. The similar ranges of fragments were obtained in the present work indicating that reproducibility of the fragments.

The band sharing was very high between the individuals within the population than compared to individuals between populations. The higher RAPD band sharing similarity indices was found between the individuals of Atlantic coast striped bass populations (Bielawski and Pumo, 1997). Based on the Nei's genetic diversity in the subdivided population, it was predicted that gene flow $(0.1032)$ will occur among these four E. machnata populations. Previous studies reported the gene flow in conserved species, Morones axatilis in Atlantic coast (Bielawski and Pumo, 1997) and in European populations of Solea solea (Exadactylos et al., 2003).

All the populations in the present investigation showed a low genetic heterogeneity. This result also coincides with previous study revealed by RAPD marker, where Nemipterus nemurus $(0.0652 \pm 0.0520)$ showed similar gene diversity than $N$. cyanomus $(0.0354 \pm 0.0208)$ and $P$. caeruleus $(0.0283 \pm 0.0197)$ (Parveen et al., 2011). Thirumaraiselvi et al. (2013) reported that the Nei's gene diversity $(\mathrm{H})$ was high $(0.0733 \pm 0.0648)$ in Cuddalore Polydactylus plebeius population compared to the Vellar $(0.0613 \pm 0.0344)$ and Pazhayar $(0.0609 \pm 0.0416)$ populations in India. The similar low level of heterogeneity was found in the previous RAPD analysis in Atlantic coast striped bass populations (Bielawski and Pumo, 1997) and catfish populations in Southern Brazil (Sofia et al., 2008). The inbreeding effect due to less population size could be one of the possible reasons for less polymorphism (Galbusera et al., 1996) and the other reason might be the effect of selection against heterozygositic population (Falconer and Mackay, 1996). 
404

There have been many reports published about technical problems associated with RAPD technique (Lynch and Milligan, 1994). The main disadvantage of RAPD is the low reproducibility of the banding pattern (Dinesh et al., 1995; Liu et al., 1999a). Dinesh et al. (1995) suggested that the reproducibility of the RAPD depends on the quality and quantity of the template DNA. Micheli et al. (1994) also confirmed experimentally the reproducibility of DNA fingerprinting of RAPD using different DNA isolation procedure. Hence, the ethanol DNA precipitation method was used for all the population with RNase treatment. Futhermore, the RAPD banding pattern of these $E$. machnata populations can be used to investigate the genetic status in the future.

Moreover, proper care given to the conditions of polymerase chain reaction has given good reproducibility results by the RAPD analysis in several fish species (Ferguson et al., 1995; Dinesh et al., 1993; Muneer et al., 2008). In the present work, there were carefully maintained the identical concentration and standardized conditions in the polymerase chain reactions for all samples in all populations. Electrophoresis conditions have also followed evenly all the primers. The present work proved again its reproducibility from the RAPD analysis in these ladyfish, $E$. machnata. Hence, this experiment revealed its reliability for genetic status of these four populations.

Nei's genetic identities between the four E. machnata populations were high and it is evident that those distinct populations were recently isolated or they were inhabited with weak geographical barriers. Similar genetic identity and genetic distance values were observed in the genetic diversity analysis of two Gangetic riverine populations of Eutropiichthys vacha using RAPD (Chandra et al., 2010). Even though they confirmed these two riverine populations vary spatially, they originate from the same drainage system. In theory, the intrapopulation genetic distance values are expected to be lower than the interpopulation genetic distance. In the present study, clustering analysis based on Nei's genetic distance performed for population relationships was congruent with geographical distance and showed the evolutionary history of the population. An incongruent was faced between the geographical distance and genetic distance among the populations Solea solea (Exadactylos et al., 2003). The significant correlation between genetic distance and geographic distance of $E$. machnata populations are at genetic equilibrium and showed the degree of differentiation and overestimate gene flow (Slatkin, 1985). Gene flow (Nm) values of 1 denote migration into an average per generation which indicates sufficient gene flow between populations to prevent population differentiation, if the populations are currently in equilibrium of migration and genetic drift. In this case, the populations have not reached genetic equilibrium and moreover there is a high probability for gene flow among the populations.

The population variation examined by RAPD loci showed low genetic population differentiation as an outcome of low natural selection in these geographical locations. Moreover, this kind of study has the ability to provide important information for future conservation management strategies. The genetic variation indices denote that there was no possibility of speciation occurring in these populations. Besides this, high genetic diversity is also essential for species to develop. Therefore, species that have less genetic variation are at a greater risk. With very little genetic variation within the specie, healthy reproduction becomes increasingly difficult and offspring is more likely to deal with problems such as inbreeding.

Several issues have been discussed regarding to marine biodiversity loss in Indian coasts. Undoubtedly there was a continuous increase in human population size in coastal areas and islands facing serious anthropogenic threats. Other reasons, such as large scale fishing, over-exploitation of marine resources, pollution and marine litter, physical alteration of watershed and coasts, land-use changes, faulty land-use practices, introduction of exotics, species invasion, increasing tourism, construction along the coasts, led to increased sedimentation, excessive use of fertilizers and chemicals in areas near coasts etc., are some of the anthropogenic activities leading to degradation, fragmentation and loss of habitats and damage to marine diversity (Saxena, 2012).

\section{Conclusion}

The RAPD profiles in the present investigation displayed a low degree of gene diversity. There is a lack of genetic heterogeneity in the samples of four populations of $E$. machnata which strongly emphasize the need of fishery management, conservation and rehabilitation of the species in these regions. Development of knowledge about life history traits, reproductive biology, ecology, genetic stock structure is the most important requirement for conservation and sustainable management of this fish fauna. Strong management strategies, such as using large number of effective population size, minimizing variance of family size, development of captive breeding technology, cryopreservation of germplasm, smallscale aquaculture programs and bans on destructive fishing practices, are some alternatives to conservation management of theses least concern species.

\section{References}

Adams AJ, Horodysky AZ, McBrideRS, GuindonK, Shenker J, MacDonald TC, Harwell HD, Ward R, Carpenter K (2013). Global conservation status and research needs for tarpons (Megalopidae), ladyfishes (Elopidae) and bonefishes (Albulidae). Fish and Fisheries, doi:10.1111/faf.12017.

Ali BA, Ahmed MMM, El-Zaeem SY (2004). Application of RAPD markers in fish: Part II: Among and within families; Cichlidae (Freshwater), Mugilidae (Catadromous), Sparidae and Serranidae (Marine). Int J Biometeorol 6:393-401.

Bardakci F, Skibinski DOF (1994). Application of the RAPD technique in Tilapia fish: species and subspecies identification. J Hered 73:117-123.

Bielawski JP, Pumo DE (1997). Randomly amplified polymorphic DNA RAPD analysis of Atlantic coast striped bass. Heredity 78(1):32-40. 
Caetano-Anolles G, Bassam BJ, Gresshoff PM (1991). DNA amplification fingerprinting using very short arbitrary oligonucleotide primers. Biotechnology 9(6):553-557.

Callejas C, Ochando MD (2002). Phylogenetic relationships among Spanish Barbus species (Pisces, Cyprinidae) shown by RAPD markers. Heredity 89:36-43.

Chandra G, Saxena Barat A (2010). Genetic diversity of two riverine populations of Eutropiichthys vacha (Hamilton, 1822) using RAPD markers and implications for its conservation. J Mol Biol 8(2):77-85.

Chong LK, Tan SG, Yusoff K, Siraj SS (2000). Identification and characterization of Malaysian river catfish Mystus nemurus ( $\mathrm{C}$ and V) by RAPD and AFLP analysis. Biochem Genet 38(3):63-76.

Clark AG, Lanigan CMS (1993). Prospects for estimating nucleotide divergence with RAPDs. Mol Biol Evol 10:1096-1111.

Dinesh KR, Lim TM, Chua KL, Chan WK, Phang VPE (1993). RAPD analysis: an efficient method of DNA fingerprinting in fishes. Zool Sci 10: 849-855.

Dinesh KR, Chan WK, Lim TM, Phang VPE (1995). RAPD markers in fishes: an evaluation of resolution and reproducibility. Asia Pac J Mol Biol Biotech 3:112-118.

Dong Z, Zhou E (1998). Application of the random amplified polymorphic DNA technique in a study of heterosis in common carp, Cyprinus carpio L. Aquac Res 29:595-600.

Exadactylos A, Geffe AJ, Panagiotaki P, Thorpe JP (2003). Population structure of Dover sole Solea solea: RAPD and allozyme data indicate divergence in European stocks. Mar Ecol Prog Ser 246:253-264.

Falconer DS, Mackay TFC (1996). Introduction to quantitative genetics. Fourth edition. Addison Wesley Longman, Harlow, Essex, UK.

Felsenstein J (1993). PHYLIP (Phylogeny Inference Package), Version 3.5. Distributed by the author. University of Washington, Seattle.

Ferguson A, Taggart JB, Prodohl PA, McMeel O, Thompson C, Stone C, McGinnity P, Hynes RA (1995). The application of molecular markers to the study and conservation of fish populations, with special reference to Salmon. J Fish Biol 47:103-126.

Frankel OH, Soule ME (1981). Conservation and Evolution. Cambridge University Press, Cambridge.

Frankham R (1996). Relationship of genetic variation to population size in wildlife. Conserv Biol 10:1500-1508.

Frankham R (2005). Genetics and extinction. Biol Conserv 126:131-140.

Galbusera P, Volckaert FA, Hellemans B, Ollevier F (1996). Isolation and characterization of microsatellite markers in the African catfish, Clarias gariepinus (Burchell, 1822). Mol Ecol 5:703-705.

Harding GC, Kenchington EL, Bird CJ, Pezzack DS, Landry DC (1997). Genetic relationships among subpopulations of the American lobster (Homarus americanus) as revealed by random amplified polymorphic DNA. Can J Fish Aquat Sci 54:1762-1771.

Heipel DA, Bishop JDD, Brand AR, Thorpe JP (1998). Population genetic differentiation of the great scallop, Pecten maximus in western Britain investigated by randomly amplified polymorphic DNA. Mar Ecol Prog Ser 162:163-171.

Hillis D, Moritz C (1990). An overview of applications of molecular systematics. In: Hillis DM, Moritz C (Eds.) Molecular systematics. Sunderland, Massachusetts: Sinauer Associates 502-515 p.

Klinbunga S, Boonyapakdee A, Pratoomchat P (2000). Genetic diversity and species-diagnostic markers of mud crabs (Genus Scylla) in Eastern Thailand determined by RAPD analysis. Mar Biotech 2:180-187.

Lande R (1995). Mutation and conservation. Conserv Biol 9:782-791.

Liu ZJ, Li P, Argue B, Dunham RA (1998). Inheritance of RAPD markers in channel catfish (Ictalurus punctatus), blue catfish (I. furcatus) and their F1, F2 and backcross hybrids. Anim Genet 29:58-62.

Liu ZJ, Li P, Argue BJ, Dunham RA (1999a). Random amplified polymorphic DNA markers: usefulness for gene mapping and analysis of genetic variation of catfish. Aquaculture 174:59-68.

Lynch M, Milligan BG (1994). Analysis of population genetic structure with RAPD markers. Mol Ecol 3:91-99.

Lynch M, Conery J, Burger R (1995). Mutational meltdowns in sexual populations. Evolution 49:1067-1080.

Mehrotra NN, Garg RKP, Sairkar N, Silawat Batav V (2010). Assessment of genetic diversity of Clarias batrachus using RAPD markers in three water bodies of Bhopal. J Env Biol 31:749-753.

Micheli M, Bova R, Pascale E, Ambrosio ED (1994). Reproducible DNA fingerprinting with the random amplified polymorphic DNA (RAPD) method. Nucleic Acids Res 22:1921-1922.

Muneer APM, Sivanandan R, Gopalakrishnan A, Basheer VS, Musammilu KK, Ponniah AG (2011). Development and characterization of RAPD and microsatellite markers for genetic variation analysis in the critically endangered yellow catfish. Biochem Genet 49:83-95.

Mwandya AW, Gullstrom M, Ohman MC, Andersson MH, Mgaya YD (2009). Fish assemblages in Tanzanian mangrove creek systems influenced by solar salt farm constructions. Estu Coast Shel Sci 82:193-200.

Nei M, Li WH (1979). Mathematical model for studying genetic variation in terms of restriction endonucleases. Proc Natl Acad Sci USA 76:5269-5273.

Nei M (1978). Estimation of average hetrozygosity and genetic distance from a small number of individuals. Genetics 89:583-590.

Nei M (1987). Molecular evolutionary genetics. Columbia Univ. Press. New York. 
406

Pal M (2012). Elops machnata. In: IUCN 2012. IUCN Red List of Threatened Species. Version 2012.2. www.iucnredlist.org.

Parveen JE, Thangaraj M, Ajithkumar TT, Bhimba BV, Rajasekar M (2011). RAPD probe on genetic variation in damsel fishes (Family Pomacentridae) in Gulf of Mannar region. Asian J Exp Biol Sci 2(4):687-690.

Pullin AS (2002). Conservation biology ( $1^{\text {st }}$ publ.). Cambridge: Cambridge University Press.

Rahman SMZ, Khan M, Islam SAS (2009). Genetic variation of wild and hatchery population of the catla India major carp (Catla catla Hamilton, 1822: Cypriniformes, Cyprinidae) revealed by RAPD markers. Gen Mol Biol 32:197-201.

Sambrook J, Fritsch EF, Maniatis T (1989). Molecular cloning: A laboratory Manual. II edn. Cold Spring Harbour Laboratory. Press, Cold Spring Harbour, N.Y.

Saxena A (2012). Marine biodiversity in India: Status and Issues. International day for biological diversity (Marine diversity).

Shaffer ML (1981). Minimum population sizes for species conservation. Bioscience 31:131-134.

Shifat R, Begum A (2003). Use of RAPD fingerprinting for discriminating two populations of Hilsa shad (Tenualo sailisha Ham) from Inland Rivers of Bangladesh. J Biochem Mol Biol 36:462-467.

Slatkin M (1985). Gene flow in natural populations. Ann Rev Ecol Evol Syst 16:393-430.
Sofia SH, Galindo BA, Paula FM, Sodre LMK, Martinez CBR (2008). Genetic diversity of Hypostomus ancistroides (Teleostei, Loricariidae) from an urban stream. Genet Mol Biol 31:317-323.

Thirumaraiselvi R, Thangaraj M, Ramanadevi V (2013). Morphometric and genetic variation in three populations of Indian salmon (Polydactylus plebeius). Not Sci Biol 5(3):275-281.

Todd CD, Walker AM, Wolff K, Northcott SJ, Walker AF, Ritchie MG, Hoskins R, Abbott RJ, Hazon (1997). Genetic differentiation of populations of the copepod sea louse, Lepeophtherius salmonis (Kroyer) ectoparasitic on wild and farmed salmonids around the coasts of Scotland: Evidence from RAPD markers. J Exp Mar Biol Ecol 210:251-274.

Welsh J, McClelland M (1990). Fingerprinting genomes using PCR with arbitrary primers. Nucleic Acids Res 18:72137218 .

Welsh J, Honeycutt RJ, McClelland M, Sobral BWS (1991). Parentage determination in maize hybrids using the arbitrarily primed polymerase chain reaction (AP-PCR). Theor Appl Genet 82:473-476.

Williams JGK, Kubelik AR, Livak KJ, Reafalski JA, Tingey SV (1990). DNA polymorphisms amplified by arbitrary primers are useful as genetic markers. Nucleic Acids Res 18:6531-6535.

Yeh FC, Yang RC, Boyle T (1999). POPGENE 32-Version 1.31. Population genetics software. 